\title{
HYSTERESIS OF TARGETING CIVILIANS IN ARMED CONFLICT
}

\section{UIH RAN LEE}

Uih Ran Lee is Lecturer in Economics at the University of Bradford, Bradford, U.K. She may be reached at u.r.lee@bradford.ac.uk.

\section{Abstract}

This article explores warring groups' intentional targeting behavior against civilians, a strictly prohibited war strategy by international norms. Using dynamic panel regressions run on a comprehensive dataset of contemporary warfare which covers 22 years (1989-2010), I find that warring actors, both sovereign states and formally organized armed groups, behave systematically in terms of civilian targeting when they are involved in prolonged armed conflict (15-22 years). Warring actors' lethal behavior against civilians tends to be intensified if targeting is repeated in prolonged armed conflict although this hysteresis effect persists only for one year. It is hypothesized that the mounting war cost of prolonged conflict inclines warring groups toward the presumably cheaper targeting of noncombatant civilians rather than battling combatant military or other armed personnel.

$\mathrm{E}_{\mathrm{i} \text { tand }}$ ven though international norms strictly prohibit the intentional targeting of civilians in any armed conflict, it is not an infrequent phenomenon. As an alternative war strategy to fighting armed combatants, civilian targeting has been carried out often in contemporary warfare. According to data compiled by the Uppsala Conflict Data Program (UCDP), from 1980 to 2010 , nearly 700,000 noncombatant civilians were killed due to direct, intentional attacks by sovereign states or by formally organized nonstate groups in armed conflicts. The intentional targeting of civilians is regarded as a typologically important strategy for the stronger actor in asymmetric conflict in order to scale down opponents' military capacity. However, barbaric acts against civilians are not restricted to stronger actors, which commonly are sovereign states. Weaker actors, including nonstate armed groups, often deliberately target civilians to prevent them from cooperating with incumbent governments and/or to draw support toward rebel groups. ${ }^{1}$

The literature on the intentional targeting of civilians in armed conflict has focused on causes of civilian victimization or its correlation with war outcomes. In relation to the former, substantial variation in the causes of such targeting is found across political (regime types, ethnic differences), economic (resource mobilization, trade openness), and geographical circumstances under which warring actors operate. Warring actors motivated by these reasons choose civilian targeting, as opposed to engaging in battles with combatants, as this is an appealing and presumably cheaper strategy to attain victory in armed conflict. $^{2}$

The persistence of the intentional targeting of civilians in prolonged armed conflict poses important policy questions due to its devastating consequences, which further jeopardize the safety of civilians in already shattering wartimes. Many have studied the persistence of armed conflict itself, but attempts to relate the duration of conflict to civilian victimization are few. Of those, Stathis Kalyvas posits that as war progresses over time, warring actors in civil war are likely to move from indiscriminate violence - $\mathrm{a}$ common form of civilian victimization - to selective violence since indiscriminate violence is cost-inefficient. Balcells and Kalyvas take this a step further by looking at warring actors' systematic behavior in different types of civil war. They find that civilian victimization is associated more with irregular wars, such as guerrilla wars, than with conventional wars as the former tend to last longer. Furthermore, another set of authors find that the longer the duration, the more likely it is that warring actors cross the line to civilian targeting at some point during conflict. These studies confirm that the duration of conflict interacts to some extent with civilian victimization, but they do not explain the temporal patterns of warring actors' behavior in terms of civilian targeting in prolonged conflict. ${ }^{3}$

This article therefore explores the persistence, or hysteresis, of warring actors' intentional targeting of civilians over prolonged armed conflict, defined as lasting 15-22 years. The longer the duration of armed conflict, the more resources are required to finance battles, and warring actors thus become more likely to concentrate lethal force on the targeting of civilians as this is cheaper than battling combatants. If warring actors are found to systematically increase the intentional targeting of civilians over time, it is necessary to eliminate incentives or factors that facilitate this behavior directed against civilians. Of particular interest in this regard is troop 


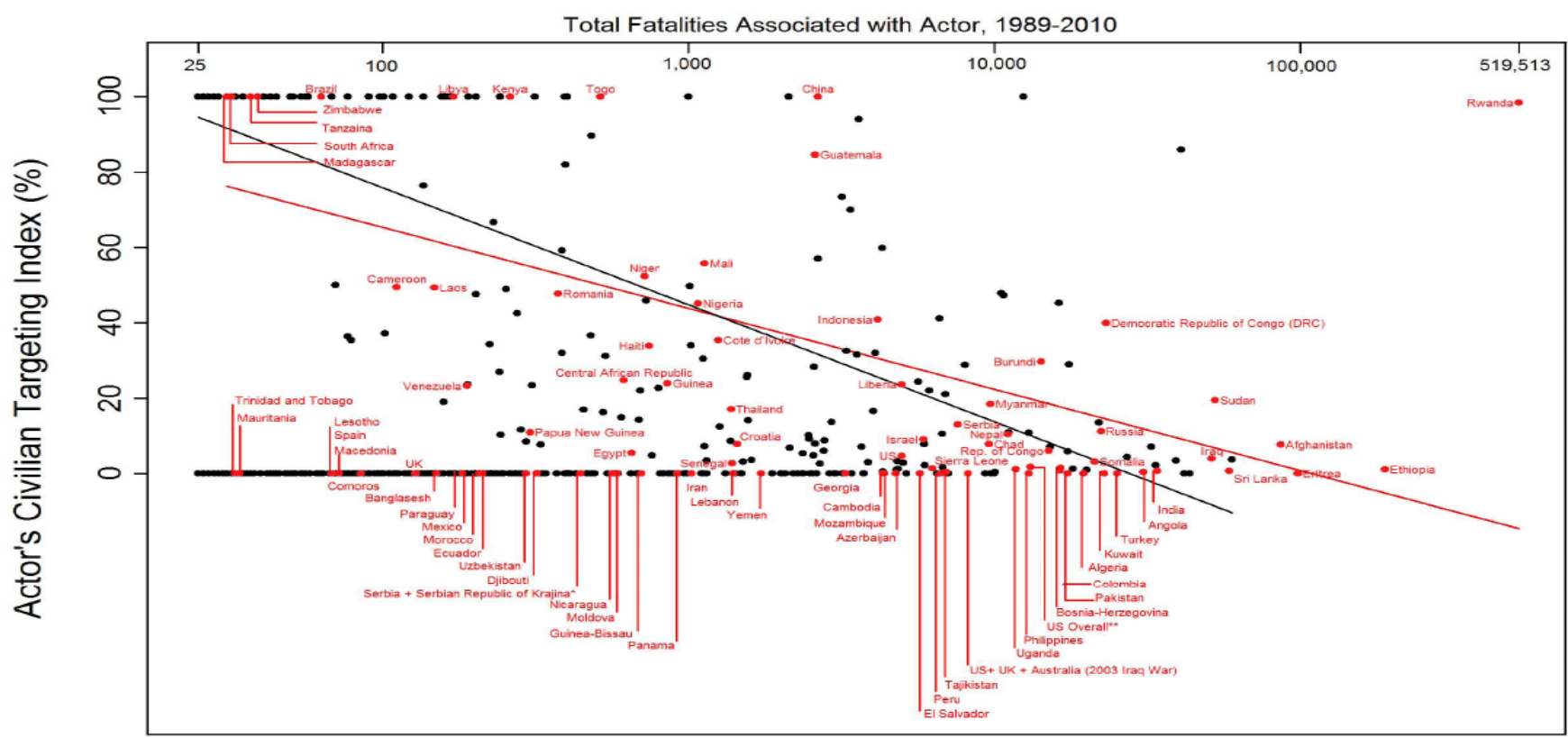

Figure 1A: Sovereign states. Global comparison of warring actors' war strategies between targeting civilians and battling combatants in armed conflict, 1989-2010. Note: Only state actors are labeled. The red and black lines are point estimates for state and nonstate actors, respectively, from a bivariate regression analysis when CIT values are regressed with total fatalities associated with actors. The estimates for both state and nonstate actors are statistically significant at the $1 \%$ level. * A state actor associated with a nonstate actor. ** Comprising the U.S. as a sole actor as well as a joint actor (i.e., U.S. associated with U.K. and Australia).

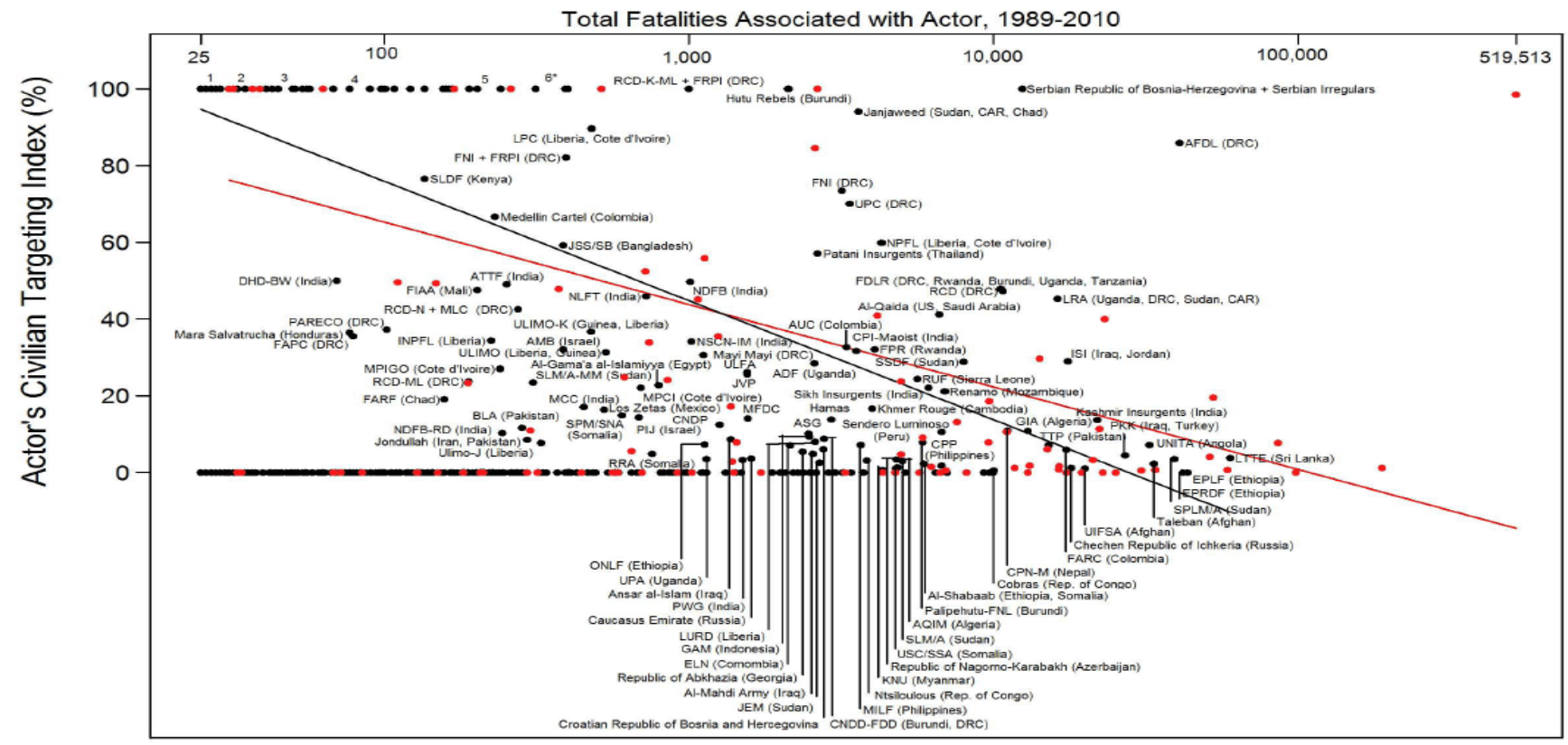

Figure 1B: Nonstate actors. Global comparison of warring actors' war strategies between targeting civilians and battling combatants in armed conflict, 1989-2010. Note: All nonstate actors with CTI $>0$ are labeled. Among the actors with CTI $=0$, only those with $>10,000$ total fatalities are labeled. * Actors with $\mathrm{CTI}=100$ are listed in the appendix. 
Table 1: Descriptive statistics. Actors involved in prolonged armed conflict versus all actors

\begin{tabular}{|c|c|c|c|c|c|c|}
\hline & \multicolumn{3}{|c|}{$\begin{array}{l}\text { CTI: Actors in prolonged conflict } \\
\qquad(15-22 \text { years })\end{array}$} & \multicolumn{3}{|c|}{ CTI: All actors (all years) } \\
\hline & States & Nonstates & All & States & Nonstates & All \\
\hline Mean & 11.03 & 9.79 & 10.54 & 20.99 & 15.83 & 16.66 \\
\hline $\begin{array}{l}\text { Confidence } \\
\text { intervals }(95 \%)\end{array}$ & $1.61-20.46$ & $3.3-16.28$ & $4.52-16.56$ & $13.93-28.05$ & $12.83-18.83$ & $13.91-19.42$ \\
\hline Standard deviation & 21.79 & 11.72 & 18.29 & 33.12 & 32.32 & 32.48 \\
\hline \multirow[t]{2}{*}{ Number of actors } & 23 & 15 & 38 & 87 & 449 & 536 \\
\hline & \multicolumn{3}{|c|}{$\begin{array}{l}\text { Total fatalities: Actors in prolonged conflict } \\
\qquad(15-22 \text { years })\end{array}$} & \multicolumn{3}{|c|}{ Total fatalities: All actors (all years) } \\
\hline Mean & $\begin{array}{c}53,891 \\
(25,209)\end{array}$ & 14,185 & $\begin{array}{c}38,217 \\
(25,209)\end{array}$ & $\begin{array}{c}17,196 \\
(11,355)\end{array}$ & 1,950 & $\begin{array}{l}4,425 \\
(3,462)\end{array}$ \\
\hline $\begin{array}{l}\text { Confidence } \\
\text { intervals }(95 \%)\end{array}$ & $\begin{array}{c}6,783-100,999 \\
(14,776-50,676)\end{array}$ & $4,781-23,588$ & $\begin{array}{c}9,653-66,782 \\
(13,886-36,533)\end{array}$ & $\begin{array}{c}4,330-30,062 \\
(5,748-16,962)\end{array}$ & $1,394-2,507$ & $\begin{array}{c}2,266-6,584 \\
(2,418-4,506)\end{array}$ \\
\hline Standard deviation & $\begin{array}{l}108,936 \\
(33,962)\end{array}$ & 16,980 & $\begin{array}{c}86,903 \\
(16,980)\end{array}$ & $\begin{array}{c}60,366 \\
(26,151)\end{array}$ & 6,003 & $\begin{array}{c}25,448 \\
(12,290)\end{array}$ \\
\hline Number of actors & $\begin{array}{c}23 \\
(22)\end{array}$ & 15 & $\begin{array}{c}38 \\
(37)\end{array}$ & $\begin{array}{c}87 \\
(86)\end{array}$ & 449 & $\begin{array}{c}536 \\
(535)\end{array}$ \\
\hline
\end{tabular}

Note: Statistics excluding Rwanda in parentheses.

size - or growth in troop size-on the notion that unless a warring actor has a strong culture of restraint, large numbers of military or paramilitary personnel increase the monitoring costs needed to prevent troops from targeting civilians. ${ }^{4}$

\section{The Civilian Targeting Index}

Prior work on civilian victimization in armed conflict typically reports findings in terms of the absolute number of war casualties, that is, death counts. However, since warring actors opt between targeting civilians and battling armed opponents, a proportional method might offer more insight into actors' behavioral options than would the analysis of total death counts alone. Toward this end, I use UCDP data to compute a Civilian Targeting Index (CTI), which is a proportional measure to quantify the degree to which warring actors intentionally employ lethal force against noncombatants as opposed to combatants. $^{5}$

To compute CTI values for each warring actor, I aggregate three UCDP datasets: (1) the one-sided violence dataset, (2) the battle-related deaths dataset, and (3) the nonstate conflict dataset. The first includes only direct and intentional killing of civilians by warring actors, either by sovereign states or by formally organized nonstate armed groups. The second, battle-related deaths dataset contains numbers of both, civilians and combatants killed in battles involving at least one state actor. As this records deaths only if the intended targets are combatants, civilian deaths included here are collateral and not intentional. The third, nonstate conflict dataset includes deaths only from battles between organized nonstate actors. The deaths recorded in these three datasets therefore are independent of each other. All data encompass warring actors and associated fatalities when deaths were at a minimum of 25 per year. UCDP documents the data based on various sources, including the news media, governmental, and nongovernmental organizations. ${ }^{6}$

When combining the three datasets, loosely organized groups contained in the nonstate conflict dataset are excluded as the one-sided violence dataset does not include them. The combined dataset thus includes 536 warring actors - namely, 87 states, and 449 formally organized nonstate armed groups as well as fatalities associated with each actor during the overlapping periods of the three datasets. The combined dataset 
covers the years 1989 to 2010. With this newly constructed dataset, one can compute each actor's CTI value, defined as the proportion of the number of civilian deaths caused by any actor's intentional and direct attacks (i.e., deaths recorded in one-sided violence dataset) to total fatalities associated with the actor (i.e., the sum of deaths recorded in the three datasets).

Panels (A) and (B) of Figure 1 display all 536 warring actors' CTI values ( $y$ axis) and, on a logarithmic scale (base 10), total fatalities associated with each actor ( $x$ axis). Panel (A) shows the labels of all 87 state actors, whereas Panel (B) shows all nonstate actors with positive CTI values. The plots elucidate which warring actors concentrate lethal force on noncombatant civilians. Most actors with CTI values of 100 - meaning that they used civilian targeting as their sole form of lethal force-are found in the upper-left quadrant of the two plots. A very large number of these actors (51 of 56) are implicated in fewer than 500 total fatalities. In contrast, actors displayed in the upper-right quadrant of the plots are associated with the bloodiest conflicts as well as to the highest rates of civilian targeting during the period of interest. For instance, Rwanda is associated with the greatest number of violent deaths, of which 98 percent were intentionally targeted civilians $(511,491$ of 519,513$)$ as shown in Panel (A). Actors with CTI values of 0 are located in the lower part of the two plots. ${ }^{7}$

\section{Actors involved in prolonged armed conflict}

While the duration of armed conflict in the dataset used for this study varies from 1 to 22 years, the majority of all actors (305 of 536) were involved in conflict lasting only one or two years. Relatively few, namely 23 state and 15 nonstate armed groups, were engaged in conflict lasting 15 years or more. ${ }^{8}$ Although the number of these latter actors is not very large, it is worth exploring their CTI values to identify the hysteresis of civilian targeting in prolonged armed conflict. Considering the overlapping confidence interval shown in Table 1, the mean CTI value for these actors does not appear to be significantly different from that of all actors, whereas the mean total fatalities associated with these actors is substantially higher than that for all actors. Figures A1 and A2, placed in the Appendix, illustrate annual CTI values of each of the actors involved in prolonged armed. Seven of them refrained from intentional and direct targeting of civilians, maintaining a CTI of 0 . The remaining actors carried out some degree of civilian targeting at some point during the armed conflict. In general, the annual CTI values of these actors display ups and downs rather than an increasing or decreasing trend.

\section{Testing strategies}

To capture any dynamic effects of CTI values, a dynamic panel approach is best suited to test for the persistence of warring actors' focus on civilian targeting, as opposed to battling combatants. Lagged CTI values are included as explanatory variables in the following regression model: 
(1) $C T I_{i t}=\alpha C T I_{i t-1}+\sum_{k=1} \beta_{k} X_{k i t}+\eta_{i}+v_{i t}$,

where the dependent variable, $C T I_{i t}$, is the CTI value of actor $i$ at time $t$. The explanatory variable of interest is the lagged dependent variable to explore the hysteresis, if any, of warring actors' lethal behavior directed against civilians. The inclusion of the control variables, $X_{i t}$, is motivated by findings of earlier studies on war duration. Of particular interest here, to estimate any scale effect of troop size on the intensity of civilian targeting, is the annual growth rate in troop size of military or paramilitary members of each warring actor. In addition, annual GDP growth in a location of incompatibility is used to control for the economic circumstances under which warring actors face armed conflict. Also included is trade openness, which is the sum of exports and imports as a share of GDP. Openness is expected to proxy for economic interdependence with the rest of the world. Two binary variables are included as well. First, external support is coded as 1 if a warring actor received external support in a given year, and 0 otherwise. Second, sovereignty is coded as 0 for state actors, and 1 for nonstate armed groups. The latter variable is included to examine whether the groups behave differently in terms of civilian targeting. Finally, $\eta_{i}$ is an unobserved, actor-specific time-invariant effect which may be correlated with other explanatory variables, and $v_{i t}$ is the disturbance term. ${ }^{9}$

Due to the endogeneity of the lag, the inclusion of the lagged dependent variable in the estimated model requires econometric methods that address the econometrics concerns arising from dynamic panel estimations. I employ GMM difference and system methods, which replace the lagged dependent variable with instruments. Also employed for robustness checks is the bias-corrected Least Squares Dummy Variable (LSDV) method as it often outperforms GMM estimators in dynamic unbalanced panels with a small sample size. This applies in this study since the number of warring actors involved in armed conflict for 15 or more years is not numerous in the dataset used for estimation. ${ }^{10}$

\section{Regression analysis}

Table 2 shows the results for simple AR(1) regressions of the lagged CTI variable and compares the estimates across the different estimation methods. Because lags of the dependent variable of an order higher than one are not significant in the GMM estimations, Table 2 presents the results for the different estimation methods for AR(1) only. As discussed by Bond, the OLS estimate is biased upward. The within-group estimate, however, is even greater than its counterpart in the GMM estimations, suggesting that the downward bias in the within-
Table 3: Hansen $J$ tests in the GMM system estimations, varying $T$

\begin{tabular}{|c|c|c|c|}
\hline & $\begin{array}{c}5-10 \\
\text { years }\end{array}$ & $\begin{array}{l}10-14 \\
\text { years }\end{array}$ & $\begin{array}{l}15-22 \\
\text { years }\end{array}$ \\
\hline \multicolumn{4}{|l|}{ Full instrument set } \\
\hline$-\mathrm{CTI}_{\mathrm{t}-1}$ & $\begin{array}{c}0.83 \\
(0.06)\end{array}$ & $\begin{array}{c}0.40 \\
(0.15)\end{array}$ & $\begin{array}{c}0.48 \\
(0.07)\end{array}$ \\
\hline - No. of instruments & 110 & 181 & 251 \\
\hline - Hansen $J p$-value & 1.000 & 1.000 & 1.000 \\
\hline \multicolumn{4}{|l|}{ Lag 1 only } \\
\hline$-\mathrm{CTI}_{\mathrm{t}-1}$ & $\begin{array}{c}0.84 \\
(0.12)\end{array}$ & $\begin{array}{c}0.39 \\
(0.21)\end{array}$ & $\begin{array}{c}0.41 \\
(0.08)\end{array}$ \\
\hline - No. of instruments & 60 & 61 & 61 \\
\hline - Hansen $J p$-value & 0.720 & 1.000 & 0.974 \\
\hline \multicolumn{4}{|l|}{$\frac{\text { Full instrument set, }}{\text { collapsed }}$} \\
\hline$-\mathrm{CTI}_{\mathrm{t}-1}$ & $\begin{array}{c}0.81 \\
(0.25)\end{array}$ & $\begin{array}{c}0.03 \\
(0.18)\end{array}$ & $\begin{array}{c}0.22 \\
(0.10)\end{array}$ \\
\hline - No. of instruments & 37 & 38 & 42 \\
\hline - Hansen $J p$-value & 0.876 & 0.998 & 0.266 \\
\hline \multicolumn{4}{|l|}{ Lag 1 only, collapsed } \\
\hline$-\mathrm{CTI}_{\mathrm{t}-1}$ & $\begin{array}{c}0.73 \\
(0.24)\end{array}$ & $\begin{array}{l}-0.03 \\
(0.16)\end{array}$ & $\begin{array}{c}0.21 \\
(0.10)\end{array}$ \\
\hline - No. of instruments & 23 & 23 & 23 \\
\hline - Hansen $J p$-value & 0.943 & 0.463 & 0.749 \\
\hline \multicolumn{4}{|l|}{ Lag 1 to 2, collapsed } \\
\hline$-\mathrm{CTI}_{\mathrm{t}-1}$ & $\begin{array}{c}0.77 \\
(0.24)\end{array}$ & $\begin{array}{c}0.03 \\
(0.19)\end{array}$ & $\begin{array}{c}0.20 \\
(0.10)\end{array}$ \\
\hline - No. of instruments & 24 & 24 & 24 \\
\hline - Hansen $J p$-value & 0.349 & 0.368 & 0.940 \\
\hline No. of obs. & 312 & 277 & 634 \\
\hline No. of groups & 71 & 29 & 38 \\
\hline
\end{tabular}

Notes: Constant is not included but year dummies included in all instrument sets. Robust standard errors in parentheses.

group estimators may be small due to the long time span in the dataset, which covers up to 22 years. The GMM and the biascorrected LSDV estimators consistently yield positive and statistically significant coefficients of the lagged CTI values, varying from 0.2 to 0.4 . Table 3 displays the GMM system estimates of the lagged CTI values with the different sets of instruments across the different time dimensions. The effect of the lagged CTI value remains largely statistically significant when considering warring actors involved in shorter periods of conflict (i.e., 5-9 years and 10-14 years), although the restriction on the number of instruments turn the hysteresis effect statistically insignificant for actors involved in conflict for 10-14 years. Overall, and consistent with Roodman (2009a; 
Table 4: Dynamic effects of civilian targeting in prolonged armed conflict (15-22 years)

\begin{tabular}{|c|c|c|c|c|c|c|c|}
\hline & (1) & (2) & (3) & (4) & (5) & (6) & (7) \\
\hline & $\begin{array}{l}\text { GMM diff. } \\
\text { One step }\end{array}$ & $\begin{array}{l}\text { GMM diff. } \\
\text { Two steps }\end{array}$ & $G M M$ sys & $G M M$ sys & GMM sys & $\begin{array}{c}\text { Bias- } \\
\text { corrected } \\
L S D V-A B\end{array}$ & $\begin{array}{c}\text { Bias- } \\
\text { corrected } \\
L S D V-B B\end{array}$ \\
\hline $\mathrm{CTI}_{\mathrm{t}-1}$ & $\begin{array}{c}0.591 * * \\
(0.190)\end{array}$ & $\begin{array}{c}0.566^{* *} \\
(0.189)\end{array}$ & $\begin{array}{c}0.551 * * \\
(0.098)\end{array}$ & $\begin{array}{c}0.543 * * \\
(0.099)\end{array}$ & $\begin{array}{c}0.552 * * \\
(0.098)\end{array}$ & $\begin{array}{c}0.392 * * \\
(0.065)\end{array}$ & $\begin{array}{c}0.406 * * \\
(0.063)\end{array}$ \\
\hline $\begin{array}{l}\text { Troop size } \\
\text { growth }\end{array}$ & $\begin{array}{l}0.004 * \\
(0.002)\end{array}$ & $\begin{array}{c}0.003 \\
(0.002)\end{array}$ & $\begin{array}{c}0.0008^{* *} \\
(0.0002)\end{array}$ & $\begin{array}{c}0.0007^{* *} \\
(0.0001)\end{array}$ & $\begin{array}{c}0.0007 * * \\
(0.0001)\end{array}$ & $\begin{array}{l}0.0007 \\
(0.014)\end{array}$ & $\begin{array}{l}0.0007 \\
(0.013)\end{array}$ \\
\hline GDP growth & $\begin{array}{c}0.034 \\
(0.154)\end{array}$ & $\begin{array}{l}-0.073 \\
(0.146)\end{array}$ & $\begin{array}{l}-0.055 \\
(0.184)\end{array}$ & $\begin{array}{c}-0.71 \\
(0.170)\end{array}$ & $\begin{array}{l}-0.055 \\
(0.186)\end{array}$ & $\begin{array}{l}-0.177 \\
(0.187)\end{array}$ & $\begin{array}{l}-0.186 \\
(0.183)\end{array}$ \\
\hline $\begin{array}{l}\text { External } \\
\text { support }\end{array}$ & $\begin{array}{c}2.836 \\
(2.770)\end{array}$ & $\begin{array}{c}2.443 \\
(2.750)\end{array}$ & $\begin{array}{c}0.868 \\
(1.130)\end{array}$ & $\begin{array}{c}1.732 \\
(1.222)\end{array}$ & $\begin{array}{c}0.866 \\
(1.146)\end{array}$ & $\begin{array}{c}2.67 \\
(3.091)\end{array}$ & $\begin{array}{c}2.769 \\
(3.070)\end{array}$ \\
\hline $\begin{array}{l}\text { Trade } \\
\text { openness }\end{array}$ & & & & $\begin{array}{c}-0.069 * * \\
(0.022)\end{array}$ & & & \\
\hline Sovereignty & & & & & $\begin{array}{c}0.787 \\
(1.525))\end{array}$ & & \\
\hline $\begin{array}{l}\text { No. of obs. } \\
\text { No. of actors }\end{array}$ & $\begin{array}{c}364 \\
32\end{array}$ & $\begin{array}{c}364 \\
32\end{array}$ & $\begin{array}{c}427 \\
35\end{array}$ & $\begin{array}{c}425 \\
35\end{array}$ & $\begin{array}{c}427 \\
35\end{array}$ & $\begin{array}{c}427 \\
35\end{array}$ & $\begin{array}{c}427 \\
35\end{array}$ \\
\hline Instruments & $\begin{array}{l}\mathrm{CTI}_{\mathrm{t}-2} \\
\mathrm{CTI}_{\mathrm{t}-3}\end{array}$ & $\begin{array}{l}\mathrm{CTI}_{\mathrm{t}-2} \\
\mathrm{CTI}_{\mathrm{t}-3}\end{array}$ & $\begin{array}{l}\mathrm{CTI}_{\mathrm{t}-2} \\
\mathrm{CTI}_{\mathrm{t}-3}\end{array}$ & $\begin{array}{l}\mathrm{CTI}_{\mathrm{t}-2} \\
\mathrm{CTI}_{\mathrm{t}-3}\end{array}$ & $\begin{array}{l}\mathrm{CTI}_{\mathrm{t}-2} \\
\mathrm{CTI}_{\mathrm{t}-3}\end{array}$ & & \\
\hline $\begin{array}{l}\operatorname{AR}(1) \\
\operatorname{AR}(2)\end{array}$ & $\begin{array}{l}-2.36 \\
1.05\end{array}$ & $\begin{array}{c}-2.39 \\
1.06\end{array}$ & $\begin{array}{c}-2.67 \\
0.93\end{array}$ & $\begin{array}{c}-2.67 \\
0.96\end{array}$ & $\begin{array}{c}-2.69 \\
0.93\end{array}$ & & \\
\hline $\begin{array}{l}\text { Sargan } \\
\text { Hansen }\end{array}$ & $\begin{array}{l}0.039 \\
0.235\end{array}$ & $\begin{array}{l}0.039 \\
0.235\end{array}$ & $\begin{array}{l}0.025 \\
0.471\end{array}$ & $\begin{array}{l}0.014 \\
0.442\end{array}$ & $\begin{array}{l}0.025 \\
0.471\end{array}$ & & \\
\hline
\end{tabular}

Note: See notes to Table 2.

2009b), collapsing the number of instruments with the use of one or two lags only (i.e., $\mathrm{CTI}_{\mathrm{t}-2}$ and $\mathrm{CTI}_{\mathrm{t}-3}$ ) appears to enhance the power of the Hansen test of the overidentifying restrictions in the GMM system estimations. ${ }^{11}$

Table 4 presents the results from dynamic panel regressions using GMM and bias-corrected LSDV estimation methods with the inclusion of the control variables. The preferred reference specification includes troop size growth, economic growth, and external support received by warring actors (specifications 1-3 and 6-7). The reference specification is obtained by running a series of iterations in which statistically insignificant economic, political, and demographic indices are largely eliminated from the analysis. Looking at the variable of interest in the reference specification (the lagged CTI value in specifications 1-3), we find that it is not just highly significant but also has a large effect size. Holding troop size growth, economic growth, and external support received by warring actors fixed, a one percentage point increase in the CTI value in the previous year increases the current year's CTI value by about 0.5 percentage points, meaning a 50 percent increase in magnitude. Of course, an individual warring actor is not expected to behave exactly as the estimates suggest because they refer to the average behavior of all actors in the sample. However, it is interesting that the Liberation Tigers of Tamil Eelam (LTTE), the rebel group that led a 25-year-long civil war against the government of Sri Lanka until 2009, approximates this predicted lethal behavior against civilians at some point in its war effort. The CTI value of LTTE increased from 0 to 2.3 between 1993 and 1994 and further increased by about 60 percent in 1995 , recording a CTI value of 3.7 with the breakout of the Third Eelam War. Conversely, the CTI value decreased by about 60 percent in the following year, recording a CTI value of 1.2.

The effect of the lagged CTI value remains highly significant, and large, in specifications 4 and 5, which take two 
more control variables into account, namely trade openness and sovereignty, a time-invariant binary variable indicating warring actors' sovereignty. Specifications 7 and 8 provide robustness tests based on the bias-corrected LSDV method. Here, the lagged CTI values are also highly significant and positive, although the magnitude is slightly smaller than in the GMM estimations. Overall, the GMM and the bias-corrected LSDV estimators consistently suggest that a one percentage point increase in a prior year's CTI value led approximately to a 0.4-0.5 percentage point increase in the current year's CTI value. This suggests the presence of a short-term (one-yearlong) memory, persistence, or hysteresis effect: Warring actors' lethal behavior against civilians is likely to be intensified if they repeat the civilian targeting in prolonged armed conflict. These results substantiate the aforementioned conjecture that war tends to get dirtier over time by involving more civilian victimization since combatant groups, in the face of mounting war costs over prolonged conflict, are inclined to targeting civilians - a cheaper strategy than battling armed opponents. This behavioral pattern remains even when those actors that never targeted civilians while involved in prolonged armed conflict are excluded from the analysis. ${ }^{12}$

In addition to the lagged CTI value, the estimates obtained for the control variables also point to important policy implications. First, troop size growth appears to positively and significantly affect the intensity of civilian targeting. Although the magnitude is small, and its effect is not statistically different from zero in the bias-corrected LSDV estimations, this should not be considered as of little importance. Instead, it may substantiate the conjecture, stated earlier, that the enforcement of restraining growing troops from killing civilians may weaken over prolonged armed conflict since maintaining a CTI of 0 requires ongoing resource expenditure to monitor troops' behavior (unless a warring actor has a strong culture of restraint from killing civilians). Second, it is noteworthy that external support, a binary variable to indicate the presence of external aid including military intervention and financial aid, is not statistically significant in any of the specifications. This may suggest that external support received by warring actors does not contribute to reducing the intensity of civilian targeting over prolonged armed conflict. Third, as expected, the effects of GDP growth are negative in most specification but the estimates are not statistically different from 0 . In contrast, trade openness, consistent with Harff (2003), does have a statistically significant negative effect (specification 4), implying that economic interdependence may contribute to reducing the intensity of civilian targeting over prolonged armed conflict. Finally, sovereignty, a variable to differentiate state from nonstate actors, indicates that being sovereign is not a significant factor influencing the intensity of civilian targeting (specification 5). This may imply that state and nonstate armed actors do not behave differently in terms of civilian targeting over prolonged armed conflict.

\section{Concluding remarks}

Covering 22 years of data (1989-2010), this article explores the persistence, or hysteresis, of actors' intentional targeting of civilians and its facilitating factors over prolonged armed conflict (15-22 years). The article yields three main findings. First, a dynamic panel data analysis identifies the presence of a short-term hysteresis effect according to which warring actors' lethal behavior against civilians tends to be intensified if they repeat civilian targeting over prolonged armed conflict. The effect persists for one year and suggests that mounting war costs in prolonged conflict may drive a warring actor toward targeting civilians rather than battling combatants, as the former is a cheaper war-fighting strategy. Second, growing troop size appears to positively affect the intensity of civilian targeting in prolonged armed conflict. Third, external support received by warring actors does not reduce the intensity of civilian targeting.

These findings carry important implications. First, warring actors - sovereign states or formally organized armed groupsengaged in prolonged armed conflict should be more carefully scrutinized by international civil society to prevent further violence against civilians and to avoid a conflict trap. Second, rapidly growing troop size should be considered as a signal that war may be about to become dirtier, involving more civilian victimization, and thus stimulate efforts directed at external intervention. Finally, external support given to warring actors may not be effectively directed toward reducing the intensity of civilian targeting.

\section{Notes}

1. Is regarded: Arreguin-Toft (2001). International norms strictly prohibit: ICRC (2010). 700,000 civilians: See the UCDP's one-sided violence dataset (http://www.pcr.uu.se/ research/ucdp/datasets/). This includes civilian deaths only by intentional and direct attacks by warring actors. Intentional killings are defined as actions deliberately taken to kill civilians; direct killings refer to civilian deaths by actors' direct attacks such as bombings and gun shots. Stronger actors: Arreguín-Toft (2001); Valentino, Huth, and Balch-Lindsay (2004). Weaker actors: Wood (2010).

2. Substantial variation: Zahar (2000); Humphreys and Weinstein (2006); Vargas (2009); Wood (2010).

3. Persistence of armed conflict itself: See, e.g., Collier and Hoeffler (1998); Collier, et al. (2003); and Collier, Hoeffler, and Söderbom (2004). Kalyvas: Kalyvas (2006). Balcells and 
Kalyvas: Balcells and Kalyvas (2014). Another set of authors: Hicks, et al. (2011).

4. The term hysteresis was coined by physicist James Alfred Ewing (1885) to denote the persistence of previous states over time in describing the magnetization of ferric materials. It has been used often in economics to explain the degree of persistence in unemployment rates. Resource required to finance battles: Collier, Hoeffler, and Söderbom (2004); Hicks, et al. (2011).

5. The CTI was initially developed by Hicks, et al. (2011).

6. UCDP data: http://www.pcr.uu.se/research/ucdp/datasets/. The nonstate dataset is included in this article since a third of formally organized armed groups contained in the dataset (71 out of 218) are also present in the battle-related deaths dataset. Twenty-five fatalities is the minimum required number for deaths to be captured in the three UCDP datasets. For the CTI computational details, refer to Hicks, et al. (2011). Note that the UCDP datasets present three different estimates of violent deaths: "best," "low," and "high." This article uses the "best" estimates, which are derived from the most reliable sources.

7. Most actors' CTI scores are distributed at the extremes: 63 percent of all actors ( 339 of 536) have values of $\mathrm{CTI}=0$ (they refrained from intentional and direct targeting of civilians and concentrated lethal force solely on combatants). Yet about 10 percent of the actors (56 of 536) have values of CTI $=100$ (they used lethal force only against noncombatant civilians). Details are available from the author.

8. Prolonged conflict of 15 or more years: Given that the maximum duration of armed conflict covered by the dataset is 22 years, the duration of 15 years is an arbitrary choice to lessen the small sample problem (e.g., for a 20 -years threshold) and to reduce the extent of unbalancedness in the panel data structure (e.g., with a 10-years threshold). For regression analyses with shorter time periods (i.e., 5-9, 10-14 years), see Table 3.

9. Earlier studies: Harff (2003); Collier, Hoeffler, and Söderbom (2004); Valentino, Huth, and Balch-Lindsay (2004). Troop size: Data from the aforemention UCDP website. When the range of the number of troops is given, the lower bound is selected for use in the regressions. GDP growth and trade openness: From the World Bank's World Development Indicators. External support: Includes various types such as military intervention and financial aid. See UCDP codebook for detailed types of external support received by warring actors (UCDP, 2011c).

10. Lagged dependent variables with instruments: Arellano and Bond (1991); Arellano and Bover (1995); Blundell and Bond (1998). Unbalanced panel with small sample size: Bruno (2005a; 2005b).

\section{As discussed by Bond: Bond (2002).}

12. Specifications 4 and 5: Trade openness and sovereignty are not included in the reference specification. As suggested by an anonymous reviewer, trade openness is not included to retain control variables measured as growth rates only (e.g., GDP growth). Sovereignty is not included since a time-invariant variable cannot be estimated with the GMM difference method. Excluded from the analysis: Results available upon request.

\section{References}

Arellano, M. and S. Bond. 1991. "Some Tests of Specification for Panel Data: Monte Carlo Evidence and an Application to Employment Equations." Review of Economic Studies. Vol. 58, No. 2, pp. 227-297. http://dx.doi.org/10.2307/2297968

Arellano, M. and O. Bover. 1995. "Another Look at the Instrumental Variables Estimation of Error Components Models." Journal of Econometrics. Vol. 68, No. 1, pp. 29-51.

http://dx.doi.org/10.1016/0304-4076(94)01642-D

Arreguín-Toft, I. 2001. "How the Weak Win Wars: A Theory of Asymmetric Conflict." International Security. Vol. 26, No. 1, pp. 93-128. http://dx.doi.org/10.1162/016228801753212868

Blundell, R. and S. Bond. 1998. "Initial Conditions and Moment Restrictions in Dynamic Panel Data Models." Journal of Econometrics. Vol. 87, No. 1, pp. 11-143. http://dx.doi.org/10.1016/S0304-4076(98)00009-8

Bond, S. 2002. "Dynamic Panel Data Models: A Guide to Micro Data Methods and Practice." Portuguese Economic Journal. Vol. 1, No. 2, pp 141-162. http://dx.doi.org/10.1007/s10258-002-0009-9

Bruno, G. 2005a. "Estimation and Inference in Dynamic Unbalanced Panel Data Models with a Small Number of Individuals." The Stata Journal. Vol. 5, No. 4, pp. 473-500.

Bruno, G. 2005b. "Approximating the bias of the LSDV Estimator for Dynamic Unbalanced Panel Data Model." Econometric Letters. Vol. 87, No. 3, pp. 115-143. http://dx.doi.org/10.1016/j.econlet.2005.01.005

Chesterman, S. 2001. "Introduction: Global Norms, Local Contexts," pp. 1-6 in Chesterman, eds. Civilians in War. Lynne Rienner Publishers.

Collier P., V. Elliott, H. Hegre, A. Hoeffler, M. Reynal-Querol, and N. Sambanis. 2003. Breaking the Conflict Trap. Washington, D.C.: The World Bank.

Collier, P. and A. Hoeffler 1998. "On Economic Causes of Civil Wars." Oxford Economic Papers. Vol. 50, No. 4, pp. 563-573.

Collier, P., A. Hoeffler, and M. Söderbom. 2004. "On the Duration of Civil War." Journal of Peace Research. Vol. 41, No. 3, pp. 253-273. http://dx.doi.org/10.1177/0022343304043769

Eck, K. and L. Hultman. 2007. "One-sided Violence against Civilians in War: Insights from New Fatality Data." Journal of Peace Research. Vol. 44, No. 2, pp. 233-246. http://dx.doi.org/10.1177/0022343307075124

Ewing, J. 1885. "Experimental Research in Magnetism." Philosophical Transactions of the Royal Society of London. Vol. 176, pp. 523-640. http://dx.doi.org/10.1098/rstl.1885.0010 
Harff, B. 2003. "No Lessons Learned from the Holocaust? Assessing Risks of Genocide and Political Mass Murder since 1955." American Political Science Review. Vol. 97, No 1, pp. 57-73. http://dx.doi.org/10.1017/S0003055403000522

Hicks, M., U. Lee, R. Sundberg, and M. Spagat. 2011. "Global Comparison of Warring Groups in 2002-2007: Fatalities from Targeting Civilians vs. Fighting Battles." PloS ONE, Vol. 6, No. 9:e23976. http://dx.doi.org/10.1371/journal.pone.0023976

Humphreys, M. and J. Weinstein. 2006. "Handling and Manhandling Civilians in Civil War." American Political Science Review. Vol. 100, No. 3, pp. 429-447. http://dx.doi.org/10.1017/S0003055406062289

[ICRC] International Committee of the Red Cross. 2010. "International Humanitarian Law." http://www.icrc.org/ eng/war-and-law/ [accessed 24 November 2014].

Roodman, D. 2009a. "A Note on the Theme of Too Many Instruments." Oxford Bulletin of Economics and Statistics. Vol. 71, pp. 135-158. http://dx.doi.org/10.1111/j.1468-0084.2008.00542.x

Roodman, D. 2009b. "How to Do xtabond2: An Introduction to Difference and System GMM in Stata." The Stata Journal. Vol. 9, No. 1, pp. 86-136.

UCDP. 2008. "UCDP One-sided Violence Codebook v.1.3." Uppsala Conflict Data Program, UCDP Database, Uppsala University.

UCDP. 2011a. "Non-State Conflict Codebook Version 2.3-2011." Uppsala Conflict Data Program, UCDP Database, Uppsala University.

UCDP. 2011b. "UCDP Battle-Related Deaths Dataset Codebook version 5.0." Uppsala Conflict Data Program, Uppsala University.

UCDP 2011c. "UCDP External Support Codebook for Details of External Support." Uppsala Conflict Data Program, Uppsala University.

Valentino, B., P. Huth, and D. Balch-Lindsay. 2004. "Draining the Sea: Mass Killing and Guerrilla Warfare." International Organization. Vol. 58, No. 2, pp. 375-407. http://dx.doi.org/10.1017/S0020818304582061

Van Bueren, G. 1994. "The International Legal Protection of Children in Armed Conflicts." International and Comparative Law Quarterly. Vol. 43, pp. 809-826.

Vargas, J. 2009. "Military Empowerment and Civilian Targeting in Civil War", HiCN Working Papers 56. Households in Conflict Network.

Wood, R. 2010. "Rebel Capability and Strategic Violence Against Civilians." Journal of Peace Research. Vol. 47, No. 5, pp. 601-614. http://dx.doi.org/10.1177/0022343310376473

Zahar, M. 2000. "Protégés, Clients, Cannon Fodder: Civilians in the Calculus of Militias." International Peacekeeping. Vol. 7, No. 4, pp. 107-128. http://dx.doi.org/10.1080/13533310008413866 


\section{Appendix}

The following list of actors, marked 1 to 6 in the upper-left hand corner of Figure $1 \mathrm{~B}$, have a score of $\mathrm{CTI}=100$. (1) MFDC-FN (Senegal); AWB (South Africa); KRA (India); Mayi Mayi Complet(DRC); PAC (South Africa); HPC (India); Buxton Gang (Guyana); SIMI (India). (2) Bakassi Boys (Nigeria); FAPC + FNI (DRC); AAH (Iraq); UPDS (India); (3) Gazotan Murdash (Russia); ACCU (Colombia); Paz y Justicia (Mexico); Salafia Jihadia (Morocco); Mayi Mayi-Ngilima (DRC); RCD-N + MLC + UPC (DRC); AFL (Liberia); Fedayeen Islam (Pakistan); Lashkar-e-Taiba (India); DHD (India); Ampatuan Militia (Philippines); (4) BLTF (India); Interahamwe, ex-FAR (Rwanda); RCD-CP (DRC); Laskar Jihad (Indonesia); RCD-LN (DRC); Mungiki (Kenya); Tawhid wal Jihad (Egypt); Indian Mujahideen (India); Jamaat Jund al-Sahaba (Iraq); FNI + FRPI + RCD-K-ML (DRC); Ranvir Sena (India); Laskar Jihad (Indonesia); FRPI (DRC); Mayi Mayi-Chinja Chinja (DRC); Rastas (Rwanda, DRC); RTC (Chad); (5) GICM (Spain); Jemaah Islamiya (Indonesia); MPGK (Mali); (6) MAGRIVI + Interahamwe (DRC); Lashkar-e-Jhangvi (Pakistan); VHP (India).
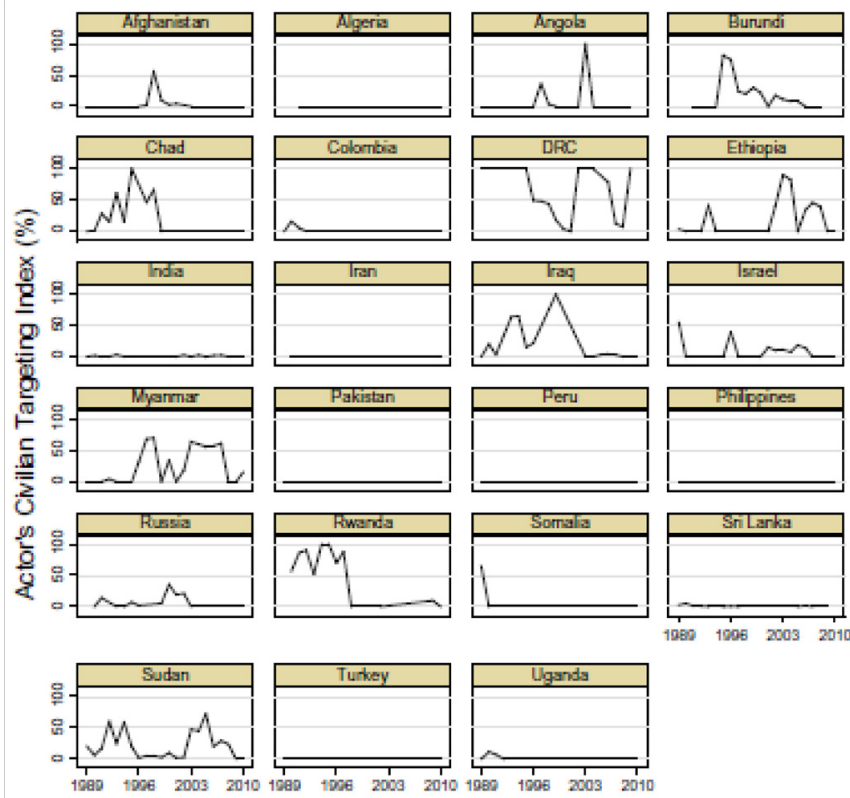

Figure A1: Annual CTI values for state actors involved in prolonged armed conflict (15-22 years).
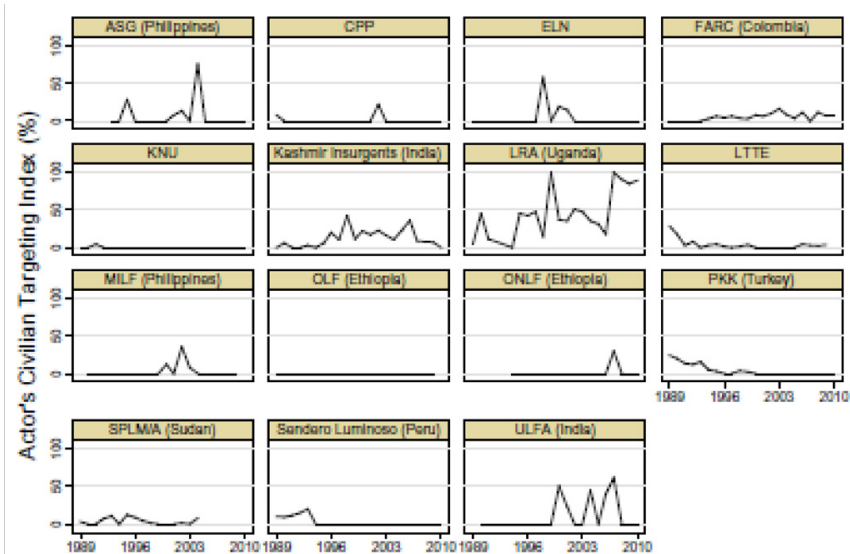

Figure A2: Annual CTI values for nonstate actors involved in prolonged armed conflict (15-22 years). 